\title{
INVESTMENTS IN RUSSIA'S REAL SECTOR OF THE ECONOMY IN MAY 2015
}

\author{
O.Izryadnova, K.Rogov
}

In May 2015, investments in capital assets amounted to 92.4\%, while in January-May 2015, to 95.2\% as compared to respective indices of 2014. A drop in investments which continues for six quarters running has been determined by a decline of business activities since H2 2012 and made worse by the macroeconomic situation early in 2015 (due to that the share of borrowed funds in the pattern of sources of funding of investments kept decreasing), complicated budget situation in regions and reduction of domestic solvent demand (which situation results in a drop in investments in building, trade and the sphere of paid services). Instability of investment demand in the primary sector of the manufacturing industry which had a positive effect on the dynamics of the domestic production in Q1 2015 is of a particular concern. At the same time, the investment situation in the engineering sector demonstrates a certain potential of import substitution.

The beginning of 2015 is characterized by worsening of the investment slump which has continued with the April-May data taken into account for six quarters running (since the beginning of 2014). In May 2015 investments in capital assets amounted to $92.4 \%$ as compared to the level of May 2014, while the volume of fulfilled jobs in building, to $89.7 \%$. So, against the post-crisis peaks of 2013 investments in Q1 2015 fell by $8.7 \%$, while in May, by $10 \%$ (against May 2013).

In Q1 2015, investments in capital assets in real terms amounted to $96.4 \%$, while the volume of fulfilled jobs in building, to $95.3 \%$ as compared to the respective period of the previous year. As a result, in Q1 2015 the share of investments in capital assets amounted to $11.5 \%$ of GDP and was 0.6 p.p. lower than the level of the respective period of the previous year.

In the pattern of investments by the type of capital assets, investments in building of nonresidential facilities and constructions were falling at a higher rate (as compared to Q1 2014 they fell even in nominal terms); investments in building of residential housing fell at a bit slower rate (Table 1). Investments in machines and equipment increased by $6 \%$ in nominal terms and as a result of that the share of those investments (as well as other investments) grew in the pattern of investments. It is to be remembered that redistribution of investment funds by the type of capital funds took place at the backdrop of changes in the pattern of prices on investment purpose products and services. With a decrease of $1.1 \%$ in prices of manufacturers of construction products in March 2015 against December 2014, the indices of prices of purchasing of investment purpose machines and equipment and other types of products and services grew by $6.6 \%$ and $6.9 \%$, respectively.

In the equity construction, the volume and share of households' funds increased with growing reduction of legal entities' funds. In Q1 2015, the funds

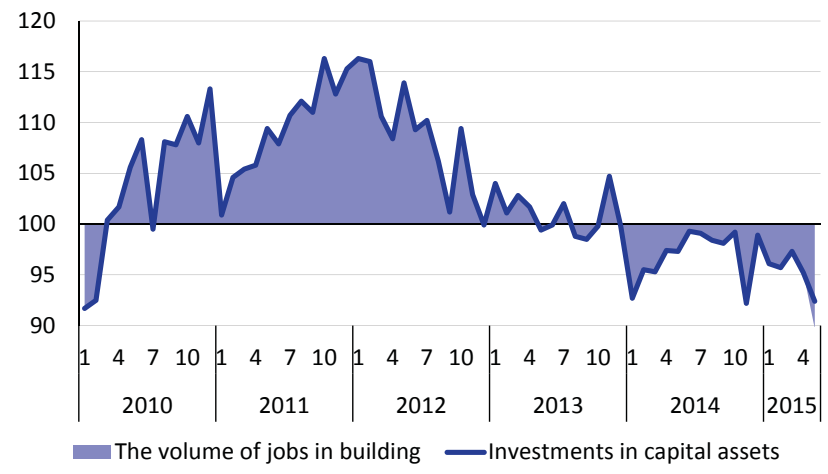

Source: The Rosstat.

Fig. 1. Dynamics of investments in capital assets and volumes of jobs in building in the 2010-2015 period as $\%$ of the respective month of the previous year

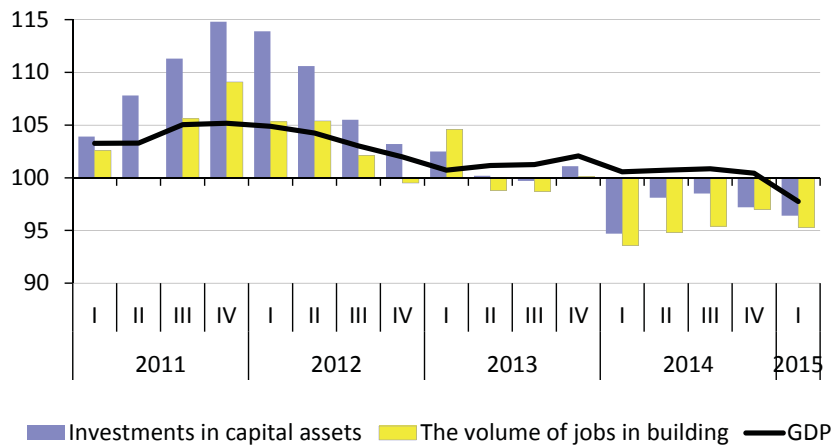

Source: The Rosstat.

Fig. 2. Dynamics of investments in capital assets in the 20112015 period as \% of the respective quarter of the previous year

received for the equity construction increased by $R b$ 3.6bn which is much lower than a RB 9.6bn growth a year ago. It is to be noted that as compared to Q1 2014 growth in households' funds for the equity construction amounted to $\mathrm{Rb} 2.5 \mathrm{bn}$ which is $75 \%$ lower than the index of Q1 2014. On the basis of the results of Q1 2015 , the volume of the extended housing loans fell 
Table 1

THE PATTERN OF INVESTMENTS IN CAPITAL ASSETS BY THE TYPE OF CAPITAL ASSETS IN Q1 2012-2015 (WITHOUT SMALL BUSINESS ENTITIES AND PARAMETERS OF INFORMAL ACTIVITIES)

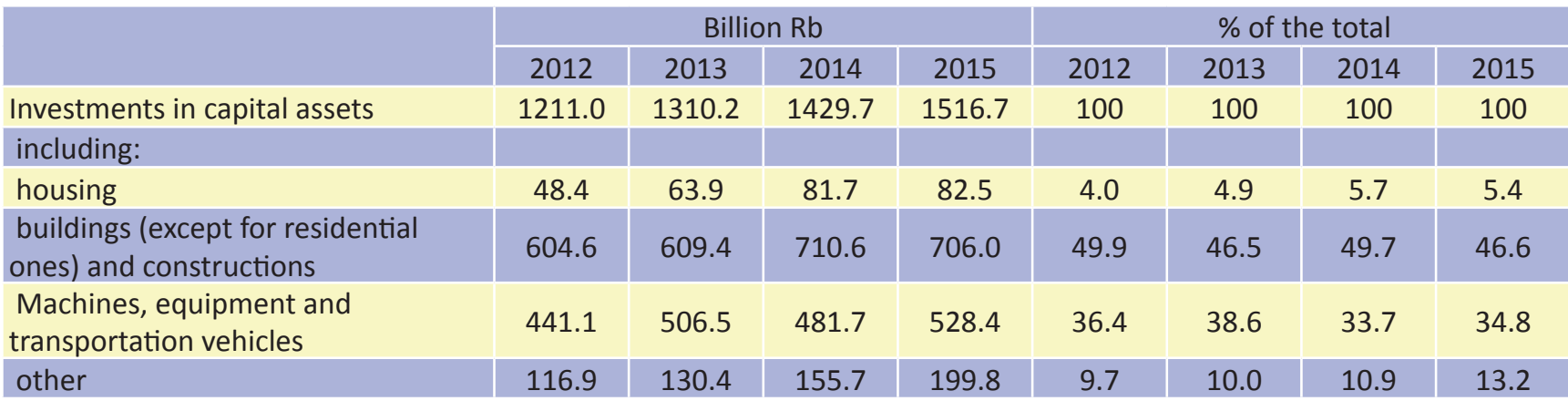

Source: The Rosstat.

Table 2

THE DYNAMICS AND PATTERN OF INVESTMENTS IN CAPITAL ASSETS BY THE TYPE OF ACTIVITIES (WITHOUT SMALL BUSINESS ENTITIES AND THE VOLUME OF INVESTMENTS WHICH ARE NOT OBSERVED BY MEANS OF DIRECT STATISTICAL METHODS) IN Q1 OF THE 2012-2015 PERIOD

\begin{tabular}{|c|c|c|c|c|c|c|c|c|}
\hline & $\%$ ag & st Q1 o & e previ & year & & $\%$ of & total & \\
\hline & 2012 & 2013 & 2014 & 2015 & 2012 & 2013 & 2014 & 2015 \\
\hline Total & 116.8 & 95.0 & 101.8 & 95.2 & 100 & 100 & 100 & 100 \\
\hline Agriculture, hunting and forestry & 116.7 & 102.5 & 98.8 & 108.6 & 3.2 & 3.3 & 3.1 & 3.4 \\
\hline Fishery and fish-farming & 161.4 & 46.4 & 82.5 & 80.8 & 0.1 & 0.1 & 0.1 & 0.1 \\
\hline Industry & 129.0 & 94.8 & 103.3 & 94.7 & 53.8 & 53.8 & 53.2 & 58.7 \\
\hline Production of minerals & 132.2 & 88.6 & 105.4 & 114.8 & 25.0 & 24.1 & 24.6 & 29.3 \\
\hline Manufacturing & 128.9 & 108.0 & 102.6 & 98.1 & 18.5 & 20.2 & 19.6 & 20.8 \\
\hline $\begin{array}{l}\text { Production and distribution } \\
\text { of electricity }\end{array}$ & 121.9 & 86.1 & 99.7 & 92.0 & 10.3 & 9.5 & 9.0 & 8.6 \\
\hline Building & 134.5 & 106.5 & 153.2 & 95.5 & 2.6 & 2.6 & 4.2 & 1.6 \\
\hline Wholesale and retail trade & 91.8 & 119.1 & 129.4 & 77.3 & 2.2 & 3.0 & 3.5 & 2.6 \\
\hline Hotels and restaurants & 40.3 & 135.4 & 64.1 & 11.3 & 0.2 & 0.7 & 0.4 & 0.3 \\
\hline Transport and communications & 106.2 & 80.9 & 110.5 & 81.3 & 24.0 & 19.5 & 19.8 & 17.8 \\
\hline Railway service & 82.1 & 94.0 & 90.0 & 86.3 & 3.7 & 3.3 & 2.8 & 2.4 \\
\hline Pipeline transportation & 107.3 & 60.8 & 113.7 & 70.3 & 10.4 & 6.6 & 6.1 & 6.0 \\
\hline Communications & 129.0 & 104.1 & 87.3 & 85.9 & 3.2 & 3.2 & 2.8 & 3.5 \\
\hline Financial activities & 140.6 & 99.8 & 108.5 & 124.9 & 1.4 & 1.6 & 1.3 & 1.7 \\
\hline Real-estate operations & 97.9 & 115.4 & 108.5 & 87.6 & 6.3 & 9.2 & 9.6 & 9.1 \\
\hline Public management & 121.3 & 80.0 & 121.6 & 98.6 & 0.8 & 0.7 & 0.9 & 0.9 \\
\hline Education & 88.7 & 116.1 & 89.7 & 125.3 & 1.2 & 1.2 & 1.0 & 1.3 \\
\hline Healthcare and social services & 125.7 & 102.9 & 66.4 & 89.3 & 1.6 & 1.6 & 1.0 & 0.9 \\
\hline
\end{tabular}

Source: The Rosstat.

by $35.5 \%$ against the previous year and amounted to $\mathrm{Rb} 222.0 \mathrm{bn}$.

In Q1 2015, commissioning of $18.6 \mathrm{~m}$ sq. meters of housing which is $32.8 \%$ more than in Q1 2014 was the result of high investment activities in the segment of residential housing development. It is to be noted that the share of individual developers has been growing: they built $51.0 \%$ of the total volume of commissioned housing against $46.7 \%$ a year ago. However, a sudden slowdown of investments in housing development in Q1 2015 (in real terms) will definitely have an adverse effect on the dynamics of commissioning of housing before the end of 2015 .
In Q1 2015, the main contribution to reduction of investments was made by a downturn of investment activities in the field of trade and paid services to households: a drop in investments in the transport and communications sectors amounted to $18.3 \%$ as compared to Q1 2014, while in trade, to $22.7 \%$ (Table 2). Growth in investments in real terms was observed in agriculture and production of fuel and energy resources.

A moderate decrease in investments in the manufacturing industry conceals a dramatic differentiation of investment activities by individual groups of production. So, investments in the machine-building complex rose by $13.8 \%$ as compared to Q1 2014, while 
Table 3

THE PATTERN OF INVESTMENTS IN CAPITAL ASSETS BY THE SOURCE OF FUNDING IN Q1 OF THE $2012-2015$ PERIOD (WITHOUT SMALL BUSINESS ENTITIES AND PARAMETERS OF INFORMAL ACTIVATES)

\begin{tabular}{|c|c|c|c|c|c|c|c|c|}
\hline & \multicolumn{4}{|c|}{ Billion $\mathrm{Rb}$} & \multicolumn{4}{|c|}{$\%$ of the total } \\
\hline & 2012 & 2013 & 2014 & 2015 & 2012 & 2013 & 2014 & 2015 \\
\hline Investments in capital assets & 1211.0 & 1310.2 & 1429.7 & 1516.7 & 100 & 100 & 100 & 100 \\
\hline $\begin{array}{l}\text { Including by the source of funding: } \\
\text { own funds }\end{array}$ & 613.3 & 693.9 & 776.5 & 891.2 & 50.6 & 53.0 & 54.3 & 58.8 \\
\hline Borrowed funds & 571.8 & 583.8 & 653.2 & 625.5 & 47.2 & 44.6 & 45.7 & 41.2 \\
\hline including: bank loans & 97.6 & 130.3 & 140.5 & 142.6 & 8.1 & 9.9 & 9.8 & 9.4 \\
\hline including loans of foreign banks & 23.2 & 15.9 & 18.2 & 31.9 & 1.9 & 1.2 & 1.3 & 2.1 \\
\hline Loans of Russian banks & 74.4 & 114.4 & 122.3 & 110.7 & 6.1 & 8.7 & 8.5 & 7.3 \\
\hline Borrowed funds of other entities & 64.4 & 94 & 87.5 & 84.6 & 5.3 & 7.2 & 6.1 & 5.6 \\
\hline Investments from abroad & n.a & n.a & 9.4 & 9.0 & 3.3 & 2.8 & 0.7 & 0.6 \\
\hline Budget funds & 133.4 & 148.4 & 137.5 & 156.7 & 11.0 & 11.3 & 9.6 & 10.3 \\
\hline including: federal budget funds & 57.0 & 70.4 & 58.6 & 79.3 & 4.7 & 5.4 & 4.1 & 5.2 \\
\hline $\begin{array}{l}\text { Budgets of constituent entities } \\
\text { of the Russian Federation }\end{array}$ & 67.8 & 67.6 & 67.2 & 67.0 & 5.6 & 5.2 & 4.7 & 4.4 \\
\hline Extra-budgetary funds & 2.9 & 6.1 & 2.7 & 2.8 & 9.2 & 0.5 & 0.2 & 0.2 \\
\hline other & 273.5 & 204.9 & 232.5 & 182.2 & 22.6 & 15.6 & 16.3 & 12.0 \\
\hline including: funds of superior institutions & 237.4 & 135.8 & 168.5 & 138.5 & 19.6 & 10.4 & 11.8 & 9.1 \\
\hline $\begin{array}{l}\text { Funds received from } \\
\text { corporate bond issues }\end{array}$ & n.a. & 0.4 & 4.0 & 22.0 & - & 0.03 & 0.3 & 1.5 \\
\hline Funds received from issuing of equities & 13.6 & 15.4 & 41.5 & 5.6 & 1.1 & 1.2 & 2.9 & 0.4 \\
\hline $\begin{array}{l}\text { Funds received for equity building } \\
\text { (legal entities' and individuals' funds) }\end{array}$ & 25.9 & 32.5 & 43.1 & 46.7 & 2.1 & 2.5 & 3.0 & 3.1 \\
\hline Including households' funds & 16.6 & 25.4 & 35.1 & 37.6 & 1.4 & 1.9 & 2.5 & 2.5 \\
\hline
\end{tabular}

Source: The Rosstat.

investments in the primary sector of the manufacturing industry kept falling: metallurgy (15.4\%) and production of charred coal and petrochemicals (14.8\%). Growth of $85 \%$ in investments in production of electric, electronic and optical equipment and that of $17 \%$ in production of machines and equipment point to a certain potential of import substitution in those sectors. It is worth mentioning growth in investments in capital assets in the chemical industry (18.4\%) and production of rubber and plastic articles (14.5\%), which situation can be related both to growth in export potential of those industries and import substitution processes.

Starting from 2012, the share of the attracted funds in the pattern of investments has been steadily decreasing: in 2011 it amounted to 58.1\%, while in 2014, only to $51.9 \%$. Early in 2015 , that trend intensified: in Q1 2015 the borrowed funds amounted to $41.2 \%$ of all the investments, while in Q1 2014, to 45.7\% (Table 3). In Q1 2015, attraction of funds for funding of investments in capital assets fell by Rb 27.7bn.

The share of bank lending decreased insignificantly (by 0.4 p.p.); it is to be noted that reduction of the share of Russian banks' loans was partially compensated by sudden growth in foreign banks' loans. As compared to Q1 2014, Russian banks' loans fell in nominal terms by $\mathrm{Rb} 11.6 \mathrm{bn}$, while foreign banks' loans increased by Rb 13.7bn.

The share of budget funds in the pattern of sources of funding of investments rose slightly as compared to Q1 2014 (in nominal terms budget investments increased by Rb 20.7bn). It is to be noted that the trend of reduction of the share of budget funds in the pattern of investments has been traced since 2012 (the share of budget investments fell from 19.2\% in 2011 to $16.2 \%$ in 2014), while the Q1 data is not indicative of the yearly dynamics. The general decrease in the share of budget investments took place due to reduction of investment resources of budgets of constituent entities of the Russian Federation which situation is a trend of the past few years, too.

In Russian practice, the funds of superior institutions are often represented by large holdings, jointstock companies and financial and industrial groups with state participation. Weakening of activities of those institutional investors in the 2013-2015 period had a rather adverse effect on the dynamics of investments. The share of investments at the expense of superior institutions in the pattern of sources of funding fell from $11.8 \%$ in Q1 2014 to 9.1\% in Q1 2015. The share of funds of superior institutions fell dramatically in the pattern of investments as early as 2013 and 
judging by the results of Q1 2015 a new turn of reduction of in-house funding is to be expected.

So, the continued reduction of investments is determined by worsening of the macroeconomic situation, that is, reduction of availability of investment resources, worsening of the budget situation in regions and a decrease in the domestic solvent demand (the above situation may result in a drop in investments in building, trade and the sector of paidservices). Instability of investment demand in the primary sector of the manufacturing industry is of a particular concern: it was that sector that lent support to domestic production in Q1 2015. At the same time, the investment situation in the machine-building sector demonstrates a certain potential of import substitution. A slump in that sector was observed as early as Q1 2014; revival of investment activities in Q1 2015 in a situation of further decrease in the output points to the fact that the sector in question has hit the local bottom. 